Legal Culture

Lex Mercatoria: A Reflexive Law Guide To An Autonomous Legal System

By Gralf-Peter Calliess

[0] EDITORIAL: The following paper was presented at the Transnational Law Conference 2001, at the Center of Transnational Law (CENTRAL) at the University of Münster on 26 October 2001

(http://www.transnational-law.de). Under the title "Transnational Business in the Age of Globalization", the Conference ? constituting also the day of the inaugurating launch of CENTRAL's Transnational Law Data Base (http://www.tldb.de) - brought together Lawyers, Judges, Arbitrators, Political Scientists as well as Sociologists, all of whom have long been working in the field of transnational law or, to use more frequent names, the lex mercatoria or law merchant. Building upon the practical expertise gained by some participants having served on arbitration tribunals or within other transnational law making agencies such as the UNCITRAL or the UNIDROIT Institute, the conference provided a forum for first-hand information and thought exchange. At the same time, CENTRAL's very focus on developments in transnational law naturally reach out to a wide range of interdisciplinary research, aptly represented by the Speakers and Discussants at the conference. Jurisprudence meets International Relations, Legal Pluralism meets Political Science, Comparative Law meets Anthropology, Law meets Politics. The research agenda could not be more ambitious, as we find ourselves confronted with the emergence of intricately complex forms of international public and private governance, involving new actors and instruments which tend to supplement or substitute traditional ways of conceiving of international relations, comparative and international law. International Law's original exclusive focus on states as legal subjects falls short of assessing the manifold picture of non-state actors on the international stage. Against this background, International Law, being a discipline usually administered by public lawyers, increasingly finds itself challenged and provoked by tireless private lawyers, sociologists, political scientists and anthropologists, offering insight into and critique of a field, which tends to escape our used ways of separating state and market, public and private. From this perspective, the border transgressing business transaction related to hugely voluminuous infrastructure building creates just as many new questions as do the media propelled indictments of human rights violations, that become known only through highly decentralized processes of scandalization.(N) $\square$ While Gralf Calliess' paper would thus fit into practically any sector of the Journal, we place it in our Legal Culture sector, hoping both to express our interest in the emerging disciplinary research agendas which so readily spring from Gralf's analysis of the legal quality of lex mercatoria, and also to underline the challenging cross-discipline nature of the following.

[1] In this presentation(1) I shall start with a brief introduction into the concept of Reflexive Law (Part I), in order to examine what makes especially Reflexive Law a promising candidate for a fruitful contribution to the ongoing debate on the normative-legal or mere social-factual status of Lex Mercatoria (Part II), and finally coming up with the suggestion of some criteria or features, which we should draw special attention on in the process of the emergence of a New Law Merchant as an autonomous legal system (Part III).

\title{
I. The Concept of Reflexive Law
}

[2] The term "Reflexive Law" was first introduced back in 1982 by Gunther Teubner.(2) Published shortly before Helmut Kohl became German chancellor the article was written in a context, where the social-liberal dreams of a political reform of society, guided by scientific-rational planning and implemented by socialengineers through the means of law had collapsed some years ago and the only alternative rising from the dust of general disillusionment with a supposedly omnipotent government were the neo-liberal and neoconservative programmes of Thatcherism and Reagonomics. Under these circumstances Reflexive Law was a somewhat clairvoyant anticipation of the late Nineties ideas of Tony Blair and Gerhard Schröder on a "third way" between market and state; on a Civil Society basically regulating itself, supported, if necessary activated, but essentially merely framed and supervised by the State. That is to say regulated selfregulation is the core political concept behind Reflexive Law. However, Reflexive Law is not meant to be a political concept in itself. To the detriment, like self-regulation it is a concept which potentially fits to all kinds of policies, from neo-conservative subsidiarity, over neo-liberal spontaneous ordering in free markets, 
to neo-socialist or communitarian ideas of democratic self-government in small and cosy parts of society. [3] In terms of legal theory Reflexive Law is quite a German concept in that it is built ? again as a kind of third way - on the descriptivist Systems Theory of Niklas Luhmann(3) and the normativist Discourse Theory of Jürgen Habermas(4). Although Teubner's book on "Law as Autopoietic System"(5) of 1989, in which the concept of Reflexive Law is elaborated, seems to be somewhat cynical and, therefore, is perceived to be a mere application of Systems Theory, there is still a lot of normative hope that we find in it, that is to say: self-regulation symbolizes Kant?s perception of freedom and autonomy as self-legislation whereas regulated represents Hegel?s hope for solidarity and rational integration of society through the State.

[4] Teubner makes a creative use of these theories by stressing the similarities rather than the differences between them. These common grounds are: Both, Luhmann and Habermas, reconstruct modern society as a communicative system, thus putting the focus neither on individuals and their actions nor on social structures and organisations, but on the process of communication. Social structures like norms, organisations, and institutions are produced and reproduced in these communicative processes. Since it is impossible for a social theory to predict the actual outcome of these manifold and highly complex processes, the emphasis is on the structures and rules which govern communication. The object of both theories, therefore, are the Meta-Rules and Meta-Structures constituting the communication society, be that the procedural discourse rules of Habermas, or the structures of social systems and subsystems of Luhmann. [5] So how come the term "Reflexive Law"? The use of reflexive as an adjective to Law is ambiguous, thereby perfectly symbolizing the intended undecisiveness of the concept in terms of Discourse vs. Systems Theory. The implications are threefold:

No. 1 Reflexive describes "an action that is directed back upon itself". For the purposes of Systems Theory reflexivity is defined as the application of a process to itself, e.g. "thinking of thinking", "communicating about communication", "teaching how to teach" etc. In the context of law reflexivity could be "making laws on law-making", "adjudicating on adjudication", or "regulating self-regulation". It is obvious, that the focus of Reflexive Law in this context is rather on procedural than on substantive law, or as H.L.A. Hart put it, on secondary rather than on primary rules. It follows, that the term Reflexive Law on the level of norms marks rules of competence and jurisdiction, of form and of procedure, all of which constitute the communicative processes by which society (including law) is regulating itself. In other words, Reflexive Law deals with Constitutions in a broad, non-technical sense. A good comparison can be seen in the contemporary work being done under the label of New Constitutional Economics.

No. 2 Another meaning of reflexive is "marked by or capable of reflection", referring to reflexion in its philosophical meaning of "introspective contemplation or consideration of some subject matter". Here one can find the normative implications of Reflexive Law as being connected with a concept of rationality. However, rationality is not understood as a quality of norms, but in accordance with Discourse Theory rather as communicative rationality. In a nutshell, decision-making in a reflexive legal system shall be marked by thorough deliberation or reasoning as well as by reflection on the specific function and limits of law in modern society. Teubner suggests, that such reflection would lead to a non-interventionist model of the State and of Law the latter of which is essentially limits itself to what we can call the constitutionalisation of self-regulation.

No. 3 Finally, a third meaning of reflexive is "a relation that exists between and entity and itself", i.e. a concept of self-reference. This leads us to the very basic concept of Autopoiesis. Let me try it again in a nutshell: Autopoieses is the self-reproduction of a system out of its own components. If a social system by definition consists out of communications, then Autopoiesis marks nothing else but the features of the system which provide for enduring communication, so that the system will not come to a sudden halt. The implications for Law as Autopoietic System are as follows: the core operations of the legal system, defined by itself as legal acts, e.g. adjudicating, legislating, contracting and the like, must be linked with each other in a way, that the mere existence of one such act provokes others, making reference to the first and thereby literally producing each other. An example for such an interlinkage of legal acts is the reference to precedent or stare decisis, by which a judgement selectively refers to some other judgements, thereby evoking the impression that it is a product of the quoted judgements. Another example is the strange interrelation between statute and judgement, where the binding act of law making produces the court decision, which at the same time by means of interpretation in the hermeneutic circle produces and reproduces the norm.(6)

\section{Lex Mercatoria: a reflexive approach to Law and Social Norms}

[6] Let me proceed with the second part, in which I intend to explain in more detail the differences, resulting from a reflexive law approach to our reflections on the concept of law and the qualities, distinguishing it from social norms.

[7] The traditional approach in jurisprudence refers to a legal system as a body of norms. Consequently the 
first 20 years of the debate over a New Law Merchant was dedicated to the question, which norms (if any) are part of or form this Lex Mercatoria and where these norms stem from. On this level of norms there are, generally speaking, two ways of giving an answer:

No. 1 First of all, a grip to the stars, to abstract natural law: general principles of law, human rights, the decalog, the common core of legal systems and the like. Obviously the Unidroit or Lando Principles belong to this category.

No. 2 Alternatively a step into the mud of facticity, i.e. concrete natural law: the essence or nature of things, custom, living law, etc. Here we find standardised contract terms, trade customs and the like.

[8] The problem with these approaches is, that they instantly provoke some standard positivist objections regarding (a) the definition of a validity test for such norms (i.e. Harts rule of recognition), (b) the legitimacy of law-making, (c) the completeness of a system of norms, and (d) the enforcement of these norms. Whereas the enforcement problem can easily be overcome within the framework of arbitration by reference to the UNCITRAL Model Law on International Commercial Arbitration, respective national Arbitration Laws as well as the 1958 New York Convention on the Recognition and Enforcement of Foreign Arbitral Awards(7), the issues of validity, legitimacy and completeness result in a vicious circle of theoretical strange loops and tautologies. It is for this reason that the New Law Merchant during the last decades developed mainly in practice under the auspices of "Cartesian pragmatism", as Klaus Peter Berger has so aptly put it.(8)

[9] Let us now turn to the possible contributions of the reflexive law approach: First of all, Systems Theory is obviously a useful analytical tool in the debate on transnational law, since it claims that Law and Politics in general are two separate and independent social systems. The intertwining of law and politics in the Constitutional Nation State in this perspective is rather a very modern and special case in social evolution. A Global Law without a State thus is a phenomenon, which Systems Theory is readily prepared to conceptualize.(9)

[10] However, more important are the differences which result from the shift of the theoretical focus from the level of norms to the level of communication. Suddenly things are very easy, for all law is positive law, i.e. is valid only by decision. To form a legal system one basically needs three communications, each raising a normative claim of validity (i.e. prescriptive speech acts): (a) a claimant (ego), (b) a defendant (alter), and (c) a court (alter ego, generalised other). These communicative acts constitute a legal system by using the Code legal/illegal (lawful/unlawful). There is no need for norms, at least not for a complete set of rules. Norms will just come naturally with the decisions, i.e. as the ratio decedendi of adjudication. Norms as the structure of a legal system are thus produced by communication, as a by-product of processing legal acts. However, a single judgment might not be sufficient to produce a norm, for norms are more abstract, they are a generalisation out of several judgments, and they are more stable, than a single case decision.

[11] Here we come back to Autopoiesis, which we defined as the mutual and perpetual referencing of different legal communications. The generation of norms is subject to the logics of remembering and forgetting, i.e. the selectivity of the communication process, by which some communicative offers for connection are accepted through reference by following communications, others are falling in oblivion. Norms thus are condensed and confirmed in the enduring process of legal discourse. To give an example, on the one hand there are judgments which somehow become leading cases or even passages from textbooks, quoted over and over again, while on the other hand there might be formal positive statutes which are not applied over a period of 25 years. Which norm is more valid, the latter or the former? For a lawyer from a Common Law background the answer might be not too puzzling.

[12] As a result we can say, that all it needs for Lex Mercatoria to become a legal system is a court, that adjudicates on it, and ? even more important? loads of disputes, offered by the international commercial community for decision under the code of Law Merchant. Lex Mercatoria as a system of norms will then flourish quasi automatically (or autopoietically) through the means of codensation and confirmation.

\section{New Law Merchant: A Global Legal System beyond the Nation State?}

[13] In conclusion, let me briefly discuss some features of the New Law Merchant, which from a Reflexive Law perspective should be highlighted as crucial in its development towards an autonomous legal system. [14] Let me start with the courts, since they form the centre of a legal system. So where precisely do we find the courts deciding on and thereby condensing and confirming the rules of a New Law Merchant? The national court-systems are not allowed to apply non-state-law. Only arbitral tribunals under certain arbitration laws may do so, if the parties have chosen to subject their dispute to general principles of law and the like. The problem is here with a lack of continuity and publicity, which hinder or even prevent the Autopoiesis of Lex Mercatoria. To give an example: In his contribution to last years CENTRAL-Conference Klaus Peter Berger cited Thayer on the Ancient Law Merchant as follows: 
"The voices of the consuls of the sea in Genoa an Barcelona found a ready echo in the maritime tribunals of Bristol and Ipswich, where the court sat on the beach and dispensed justice to passing mariners between tide and tide."(10)

[15] Here we see a court as a physically localised institution, offering its dispute resolution services. It sits on the beach, close to demand at the dispute-market, thus providing easy access to justice. But dispute resolution is only a service provided, but not an end in itself. For a legal system has the function of producing certainty in normative expectations for a community subjected to its jurisdiction. For "Certainty is so essential, that law cannot even be just without it", as Francis Bacon observed. Or as the Law and Economics approach would put it, law is all about reducing transaction costs. But as we have seen above, norms and thus certainty can only be generated, if the legal system provides for self-reference, thus starting the process of condensation and confirmation of norms according to the logics of remembering and forgetting.

[16] One possible feature of a legal system, enabling Autopoiesis, is a locally institutionalised court, which will develop a kind of collective or institutional memory. Under the very basic rule of formal justice, i.e. treating equal cases equal, the court on the beach will start its own legal history and decide repeating disputes by reference to its own precedent. Another very important feature is, that the court sits in public, thereby allowing its rulings to be spread through oral tradition by the observing mariners and finally to be echoed by other tribunals and vice versa. As a result, over time there will evolve a body of marine rules, constituting a legal system that provides sufficient legal certainty.

[17] If we take a look on today's practice of international commercial arbitration, however, we find delocalised and non-public proceedings of ad hoc tribunals put together by selection of the parties for a single case. No self-reference, no self-observation, no Autopoiesis in sight? Well, as Niklas Luhmann would suggest, we ought to search for functional equivalents to continuity and publicity.

[18] Regarding continuity in international commercial arbitration we may find such functional equivalent in the different arbitration institutions like the ICC. Strikingly, these institutions sometimes call themselves Court like the London Court of International Arbitration or the International Court of Arbitration of the ICC. Although the latter is not a court, since the decision of a case under the ICC Arbitration Rules remains with the Arbitral Tribunal which is still put together ad hoc by the parties, it provides an institutional framework which may be suitable for Autopoiesis. Article 27 of the ICC Rules provides that each Award before signing shall be submitted in draft to the Court.(11) The Court exercises a revision with regard to the form of the award, i.e. binding approval, and a supervision with regard to the substance, i.e. it may give non-binding advice. The mere fact of a central body auditing every award, including those applying Lex Mercatoria, may imply the existence of a institutional memory as described above.

[19] But this memory remains private. Although there is no evidence for a corresponding practice, under Art. 27 the Court could, for instance, provide precedent to tribunals dealing with Lex Mercatoria. However, this would not contribute to legal certainty, as long as the generated rules were not published. On the other hand, publicity does not necessarily mean public proceedings. The judgments of the Federal Court of Justice in Germany for instance, are published generally in an anonymous form regarding the parties and facts of the case, and often as well in a short form with respect to the legal arguments, revealing the ratio decidendi rather than any case specific details. There is something similar as well in international commercial arbitration, e.g. when some ICC Awards are published in Clunet or involved arbitrators are reporting on their decisions in law journals.

[20] But the reported materials are still very little and not easy available, thus preventing the evolution of another feature of Autopoiesis, the self-observation of a legal system through legal dogmatics in universities, which play an important role in systematizing the material, offered by adjudication, and in handing down the knowledge of a legal system to generations of lawyers to come. The Unidroit- and LandoPrinciples do belong into this context. They find their historical predecessors in the compilations of law, which were published by private monks in the eleventh century, the time when the western legal tradition was founded, as Harold Berman in his book on "Law an Revolution"(12) argued, and when, according to Luhmann, the Autopoiesis of Law emerged for the first time.

[21] However, these compilations of principles are somehow to abstract, in that they are not derived from actual adjudication but from the common core of legal systems as perceived by some famous comparative lawyers. A step further is the CENTRAL List, which combines the principles with references to arbitral precedent in Lex Mercatoria.(13) But all these lists become valid law only by reference of the parties of an international commercial contract. And here the New Law Merchant is competing with other national private law jurisdictions. At the end of the day, the international commercial community and, even more important, its legal advisors have to be convinced, that the New Law Merchant is a competitive legal system, and that is ? as opposed to being merely a tool of alternative dispute resolution ? a normative system 
reducing transaction costs in global business by generating legal certainty.

[22] Let me conclude with the following remarks: If asked for advice on the transformation of the New Law Merchant into an autonomous legal system, Niklas Luhmann would answer, "the better it works, the better it works." That is to say: It is all a matter of communication. Or to put it in the words of a famous German news-speaker: "Do good, and talk about it!" Personally I have the impression, that in terms of providing free and easy access to systematic knowledge of Lex Mercatoria and thereby enabling self-reference, the CENTRAL Transnational Law Database launched today(14) could be a milestone on the road to the New Law Merchant as an Autopoietic System.

$\square$ (N) See, e.g. , the contributions to EMERGING LEGAL CERTAINTY: EMPIRICAL STUDIES ON THE GLOBALIZATION OF LAW (VOLKMAR GESSNER/ALI CEM BUDAK EDS. 1998); Sally Falk Moore, Law as Process: An Anthropological Approach (1978); idem., Law and Social Change: The SemiAutonomous Legal Field as an Appropriate Field of Study, in: 7 LAW AND SOCIETY REVIEW 719-746 (1973); Christian Joerges, Vorüberlegungen zu einer Theorie des internationalen Wirtschaftsrechts, in: 43 RABELSZ 6-79 (1979); Mathias Albert, Introduction: World Society, in: CIVILIZING WORLD POLITICS. SOCIETY AND COMMUNICATION BYOND THE STATE (M. Albert/L. Brock/K1.-D. Wolf Eds. 2000), 1-17; Klaus Günther/Shalini Randeria, RECHT, KULTUR UND GESELLSCHAFT IM PROZEß DER GLOBALISIERUNG, Werner Reimers Stiftung, Schriftenreihe: Suchprozesse für innovative Fragestellungen in der Wissenschaft, Heft Nr. 4 (2001); THE PRACTICE OF TRANSNATIONAL LAW (KLAUS PETER BERGER ED. 2001); Yves Dezalay \& Bryant G. Garth., DEALING IN VIRTUE (1996); Gunther Teubner, GLOBAL LAW WITHOUT A STATE (1997): idem., Privatregimes: Neo-Spontanes Recht und duale Sozialverfassungen in der Weltgesellschaft?, in: ZUR AUTONOMIE DES INDIVIDUUMS ? LIBER AMICORUM FÜR SPIROS SIMITIS (DIETER SIMON/MANFRED WEISS EDS. 2000), 437-453; Peer Zumbansen, Spiegelungen von ?Staat und Gesellschaft": GovernanceErfahrungen in der Globalisierungsdebatte, in: STEUERUNGSFÄHIGKEIT DES RECHTS UNTER DEN BEDINGUNGEN DER GLOBALISIERUNG (Anderheiden/Huster/Kirste Eds. 2001), ARSP-Beiheft 79, $13-40$.

(1) Presented at the CENTRAL Conference "Transnational Business in the Age of Globalization" in Muenster, Germany, on October 26, 2001 (www.transnational-law.de). I want to thank Peer Zumbansen for helpful comments.

(2) G. Teubner, Reflexives Recht, ARCHIV FÜR RECHTS- UND SOZIALPHILOSOPHIE, 1982, p. 13et seq.

(3) N. Luhmann, Soziale Systeme, Frankfurt 1984; engl. Social Systems, Stanford UP 1995; N. Luhmann, Das Recht der Gesellschaft, Frankfurt 1993.

(4) J. Habermas, Faktizität und Geltung, Frankfurt 1992; engl. Between Facts and Norms, MIT Press 1996.

(5) G. Teubner, Recht als autopoietisches System, Frankfurt 1989; engl. Law as Autopoietic System, London 1993.

(6) See for an extensive discussion of these concepts G. Calliess, Prozedurales Recht 1999.

(7) See the contributions of Berger, Sanders, and Nienaber in: Center for Transnational Law (ed.), Understanding transnational Commercial Arbitration, CENTRAL Practice and Study Guides Vol. 2, Muenster 2000.

(8) K. P. Berger, The New Law Merchant and the Global Market Place, in: Berger (ed.), The Practice of Transnational Law, Kluwer 2001, p.1, 3.

(9) See G. Teubner, "Global Bukowina": Legal Pluralism in the World Society, in: G. Teubner (ed.), Global Law without a State, Dartmouth 1997; G. Teubner, Breaking Frames: The Global Interplay of Legal and Social Systems. THE AMERICAN JOURNAL OF COMPARATIVE LAW 45, 1997, 149; G. Calliess, Globale Kommunikation? staatenloses Recht, Supplement to ARCHIV FÜR RECHTS- UND SOZIALPHILOSOPHIE 79 (2001), 61 et seq. 
(10) Thayer, BROOKLYN LAW REVIEW, 1936, 139, 141; quoted by K. P. Berger, The New Law Merchant and the Global Market Place, op. cit. at 4.

(11) Y. Derains, The ICC Arbitration Rules, in: CENTRAL PRACTICE AND STUDY GUIDES Vol. 2, 58

(12) Harold J. Berman, Law and Revolution. The Formation of the Western Legal Tradition, p. 85, 87

(1983); in German: Recht und Revolution, Frankfurt 1991.

(13) K. P. Berger, Formalisierte oder schleichende Kodifizierung des transnationalen Wirtschaftsrechts, Berlin 1996; Engl. The Creeping Codification of the Lex Mercatoria, Kluwer 1999.

(14) See www.tldb.de and www.transnational-law.de 